\title{
Titanium-Niobium Alloy Thin Films at Substrate Temperature (100C,200C and 300C) using Field Emission Scanning Electron Microscopy
}

\author{
Aditi, Anand. K. Tyagi
}

\begin{abstract}
This study reports on microstructural characteristics of Titanium-Niobium thin films deposited by $R F$ Magnetron sputtering on glass substrate as a function of substrate temperature. The salient features of Ti-Nb films have been investigated by using high quality images of Field emission scanning electron microscopy (FESEM) and EDX, which enables the study of the film microstructure, elemental composition and grain size. The grain size is found to be sensitive to the $\mathrm{Nb}$ content at all substrate temperatures studied for all compositions. Further, the Grain size also exhibited the composition dependence; it reduces drastically from $114 \mathrm{~nm}$ for alloy Ti90Nb10 to $21 \mathrm{~nm}$ for alloy Ti50Nb50. EDX analysis of the thin film samples validates their elemental composition.

Keywords: Ti-Nb alloy, RF Magnetron Sputtering, Grain size, Microstructure, FESEM
\end{abstract}

\section{INTRODUCTION}

The microstructural and surface characteristics of Titanium and Niobium alloys thin films play a vital role in deciding their application potential, as these strongly influence the functional properties of this alloy system. The $\mathrm{Ti}-\mathrm{Nb}$ thin films, suitably tailored, may be used in many engineering applications covering a variety of areas such as aerospace, marine, biomaterials, chemical industries, sports, microelectronics, medical instruments etc. A systematic investigation on the influence of substrate temperature and composition of $\mathrm{Ti}_{1-\mathrm{x}} \mathrm{Nb}_{\mathrm{x}}$ alloys $(\mathrm{x}=0.10,0.20,0.30,0.40$ and 0.50 ) on the microstructural and surface characteristics of $\mathrm{Ti}-\mathrm{Nb}$ thin films, is essential for chalking out a strategy to tailor their chattels like strength, roughness and adhesion suitable to specific applications. Owing to these facts, the present work has been focused on depositing the Titanium-Niobium films with varying compositions $\left(\mathrm{Ti}_{1-\mathrm{x}} \mathrm{Nb}_{\mathrm{x}} ; \mathrm{x}=0.10-0.50\right)$ on glass substrate at different temperatures i.e. $100^{\circ} \mathrm{C}, 200^{\circ} \mathrm{C}$ and $300^{\circ} \mathrm{C}$ by RF Magnetron Sputtering followed by their microstructural, topographic and elemental characterization.

Usually, TEM and SEM are most frequently used in the study for microstructural and morphological investigations of thin film coatings [1-3]. The TEM technique has seen some limitations like the TEM experimental equipment is expensive; the analysis is time-consuming and is highly

Revised Version Manuscript Received on 16 September, 2019.

* Correspondence Author

Aditi, Department of applied sciences, Punjab Technical university, kapurthla(Punjab)

Anad.k.Tyagi, Professor, Department of applied sciences, SBS State Technical Campus, Ferozpur(Punjab) skill-oriented. Compared with conventional SEM, Field Emission Scanning Electron Microscopy (FESEM) produces much better, more clearer, less electrostatically distorted images means much better than conventional SEM. The advanced FESEM based studies have suggested significant advantages like: focusing with higher resolution, ability to measure microstructural and morphological properties and potential of imaging in highly accurate manner [4-6].

Unlike conventional techniques; like SEM, TEM, AFM, FTIR, SAXS and XPS, earlier used for morphological characterization, microstructural evolution and Surface topographical studies of the Ti-Nb alloy thin films, FESEM provides an ultra-high resolution characterization \& analysis giving precise true nanometer scale information of these alloys[7-13].

In the present work we have used FESEM (Nova Nano FE-SEM 450) (FEI) with a resolution of $1.4 \mathrm{~nm}$ at $1 \mathrm{kV}$ (TLD-SE) \& $1 \mathrm{~nm}$ at $15 \mathrm{kV}$ (TLD-SE). The EDX facility attached to this equipment is used for measuring the elemental chemical composition of the deposited thin film samples. The data produced by EDX analysis consist of spectra showing peaks corresponding to the elements making up the true composition of samples being analyzed. It also provides elemental mapping and image analysis of the given sample. All the 15 thin film samples, synthesized in this study were characterized with FESEM/EDX and results of all samples are evaluated to investigate the effect of variation in substrate temperature and increase in niobium content in $\mathrm{Ti}-\mathrm{Nb}$ alloy thin films on the grain size.

\section{EXPERIMENTAL DETAILS}

The Ti-Nb films were deposited by RF magnetron sputtering onto glass substrates using Titanium- Niobium alloy target (50-mm diameter and 3-mm thick) with a minimum purity of $99.9 \%$. The glass substrates were cleaned by rinsing in ultrasonic bath of acetone for 10-15 minutes and dried. Glass substrates were cut into different sizes of requirement and clamped on the substrate holder in the chamber. Vacuum was created in the sputtering chamber not less than $10^{-6}$ Torr by using a turbo molecular pump. Commercial Argon (Ar) gas of $99.9 \%$ purity was used as the sputtering gas and it was kept constant at gas flow rate of 15 sccm that was controlled by a mass flow controller. Base pressure was kept at $8 \times 10^{-6}$ mbar and working pressure was $1.7 \times 10^{-2}$ mbar. In this process target-substrate distance was

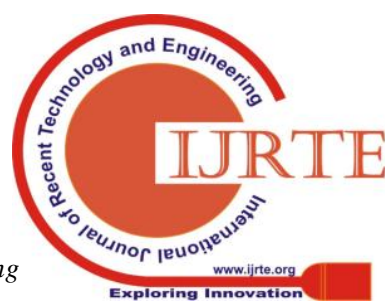


kept at 7-8 cm. Sputtering RF power and thickness were kept constant at $100 \mathrm{~W}$ and $200 \mathrm{~nm}$ respectively. The thin films were deposited for five different compositions of the targets (mentioned below) at three different substrate temperatures of $100^{\circ} \mathrm{C}, 200^{\circ} \mathrm{C}$ and $300^{\circ} \mathrm{C}$.

- Target 1: (Ti90Nb10):- in this sample atomic weight percentage of $\mathrm{Nb}$ is $10 \%$ and mass weight percentage is $17.7 \%$ of whole alloy.

- Target 2: (Ti80Nb20):- in this sample atomic weight percentage of $\mathrm{Nb}$ is $20 \%$ and mass weight percentage is $33 \%$ of whole alloy.

- Target 3: (Ti70Nb30):- in this sample atomic weight percentage of $\mathrm{Nb}$ is $30 \%$ and mass weight percentage is $45 \%$ of whole alloy.

- Target 4: (Ti60Nb40):- in this sample atomic weight percentage of $\mathrm{Nb}$ is $40 \%$ and mass weight percentage is $56 \%$ of whole alloy.

- Target 5: (Ti50Nb50):- in this sample atomic weight percentage of $\mathrm{Nb}$ is $50 \%$ and mass weight percentage is $66 \%$ of whole alloy.

\section{RESULTS AND DISCUSSIONS}

Firstly, we have recorded the FESEM micrographs of all the thin film samples of Titanium - Niobium alloys (Ti90Nb10, Ti80Nb20, Ti70Nb30, Ti60Nb40 and Ti50Nb50) deposited on glass substrate at a temperature of $100^{\circ} \mathrm{C}$. In order to facilitate ready comparison of the microstructural features of the samples synthesized, the micrographs are shown in Fig. 1(a - e) with (1) and (2) indicating the $50 \mathrm{k}$ and $200 \mathrm{k}$ image magnifications respectively. The $\mathrm{Nb}$ particles are found to be of white color and $\mathrm{Ti}$ particles are of dark grey color in the micrographs. Clearly with the increase in $\mathrm{Nb}$ content, more and more white spots are visible in the micrographs. The grain sizes of all these samples were calculated from online software 'Image J' and average method with images of $200 \mathrm{k}$ magnification.

Table 1: Grain size of Ti-Nb alloy at $100^{\circ} \mathrm{C}$

\begin{tabular}{|l|l|l|l|l|l|}
\hline $\begin{array}{l}\text { Sample } \\
\text { composition }\end{array}$ & $\begin{array}{l}\text { Ti90Nb } \\
10\end{array}$ & $\begin{array}{l}\text { Ti80Nb } \\
20\end{array}$ & $\begin{array}{l}\text { Ti70Nb } \\
30\end{array}$ & $\begin{array}{l}\text { Ti60Nb } \\
40\end{array}$ & $\begin{array}{l}\text { Ti50Nb } \\
50\end{array}$ \\
\hline $\begin{array}{l}\text { Grain size (in } \\
\text { nm) }\end{array}$ & 114 & 105 & 90 & 62 & 21 \\
\hline
\end{tabular}

The Table 1 shows the values of grain size as a function of sample composition. Clearly, with an increase in $\mathrm{Nb}$ content the grain size decreases from $114 \mathrm{~nm}$ to $21 \mathrm{~nm}$.

The decrease in grain size is found to be accompanied by a decrease in the film roughness. With decrease in grain size, boundaries of thin films become smoother.

Roughness arises from boundaries between grains; the more number of grains means lesser space between the grains, which means less roughness. Increased grain size means reduced number of grains and therefore larger boundaries and hence higher roughness. As a general observation, all the samples are found to have uniform distribution of nano-grains and as $\mathrm{Nb}$ content increases from $10 \%$ to $50 \%$, the size of the grains decreases and surface becomes smoother and compact. It can further be noticed that an increase in $\mathrm{Nb}$ content led to increased homogeneity of distribution of $\mathrm{Ti}$ and $\mathrm{Nb}$ on SEM images.

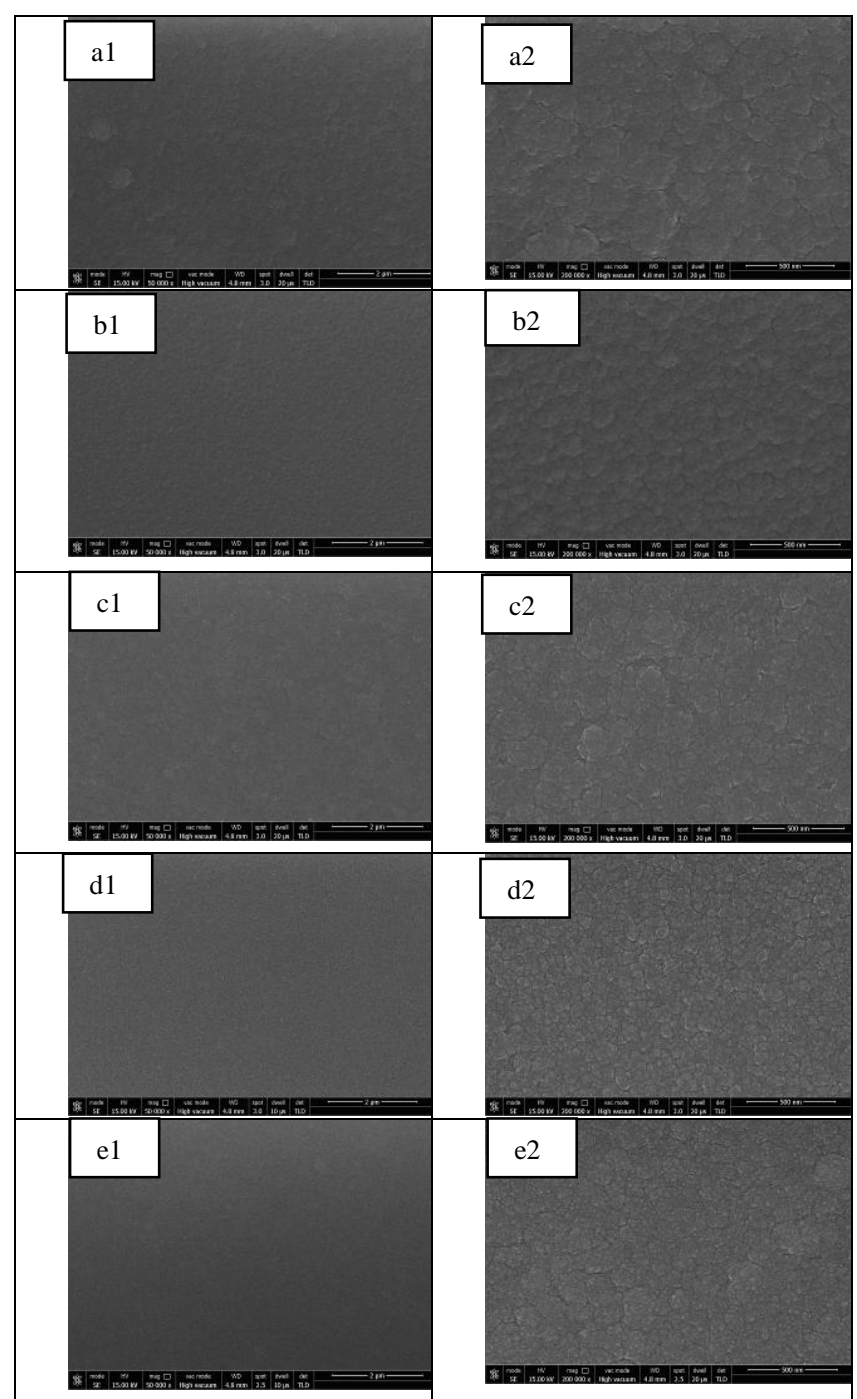

Fig. 1: SEM Images of Ti-Nb Alloys at Different Magnification a(1) 50k, a(2) 200k of Ti90Nb10, b(1) 50k, b(2) $200 \mathrm{k}$ of Ti80Nb20, c(1) $50 \mathrm{k}$, c(2) $200 \mathrm{k}$ of Ti70 Nb30, d(1) $50 \mathrm{k}, \mathrm{d}(2) 200 \mathrm{k}$ of Ti60Nb40, e(1) $50 \mathrm{k}$, e(2) $200 \mathrm{k}$ of Ti50Nb50 at $100^{\circ} \mathrm{C}$

Density of films has increased as evident from with lesser fraction of voids in the microstructure. Clearly, with an increase in $\mathrm{Nb}$ content, the morphology of the grain changes and becomes denser due to higher surface area and bulk diffusivity of sputtered atoms. Grains are found to size in nano- regime with regular shape, and a change in nano-crystallinity is observed as a function of $\mathrm{Nb}$ content.

In the second phase of the study, we have examined the characterization of thin films of Titanium and Niobium alloy of (Ti90Nb10, Ti80Nb20, Ti70Nb30, Ti60Nb40 and Ti50Nb50) deposited at substrate temperature of $200^{\circ} \mathrm{C}$. We have recorded the FESEM micrographs of all the samples as

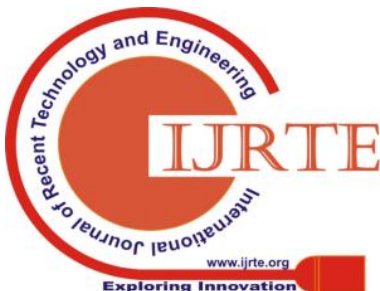


shown in Fig. 2(a - e) with (1) and (2) indicating the 50k and 200k magnifications of the images respectively. Grain sizes of alloys are given in Table 2.

Table 2: Grain size of Ti-Nb alloy at $200^{\circ} \mathrm{C}$

\begin{tabular}{|l|l|l|l|l|l|}
\hline $\begin{array}{l}\text { Sample } \\
\text { composition }\end{array}$ & $\begin{array}{l}\text { Ti90Nb } \\
10\end{array}$ & $\begin{array}{l}\text { Ti80Nb } \\
20\end{array}$ & $\begin{array}{l}\text { Ti70Nb } \\
30\end{array}$ & $\begin{array}{l}\text { Ti60Nb } \\
40\end{array}$ & Ti50Nb50 \\
\hline $\begin{array}{l}\text { Grain size (in } \\
\text { nm) }\end{array}$ & 59 & 48 & 42 & 38 & 35 \\
\hline
\end{tabular}

Clearly, with an increase in $\mathrm{Nb}$ content from $\mathrm{Ti} 90 \mathrm{Nb} 10$ to Ti50Nb50, the grain size decreases from $59 \mathrm{~nm}$ to $35 \mathrm{~nm}$. The decrease in grain size is found to be accompanied by a decrease in the film roughness. With decrease in grain size, boundaries of thin films become smoother. But in this case decrease in grain size is not substantial as earlier case at $100^{\circ} \mathrm{C}$. Grain size has decreased gradually to $35 \mathrm{~nm}$ and we can clearly see these patterns in the fig 2 .

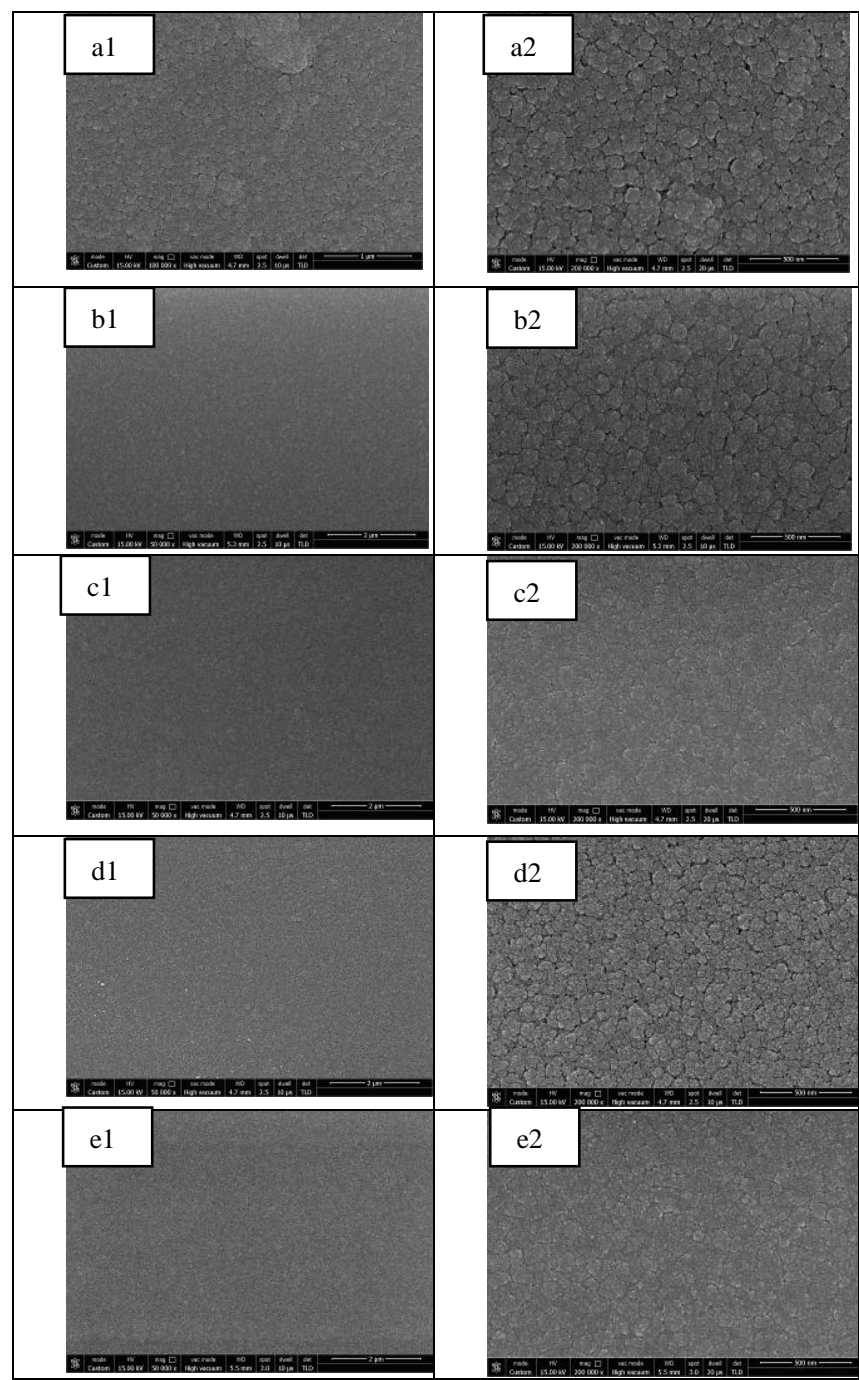

Fig. 2: SEM Images of Ti-Nb Alloys at Different Magnification a(1) 50k, a(2) 200k of Ti90Nb10, b(1) 50k, b(2) $200 \mathrm{k}$ of Ti80Nb20, c(1) $50 \mathrm{k}$, c(2) $200 \mathrm{k}$ of Ti70 Nb30, d(1) $50 \mathrm{k}, \mathrm{d}(2) 200 \mathrm{k}$ of Ti60Nb40, e(1) $50 \mathrm{k}$, e(2) $200 \mathrm{k}$ of Ti50Nb50 at $100^{\circ} \mathrm{C}$

In the third phase of investigations, we have examined the characterization of thin films of Titanium and Niobium alloy of (Ti90Nb10, Ti80Nb20, Ti70Nb30, Ti60Nb40 and
Ti50Nb50) deposited at $300^{\circ} \mathrm{C}$. We have recorded the FESEM micrographs of all the samples as shown in Fig. 3(a e) with (1) and (2) indicating the $100 \mathrm{k}$ and $200 \mathrm{k}$ magnifications of images of the respectively.

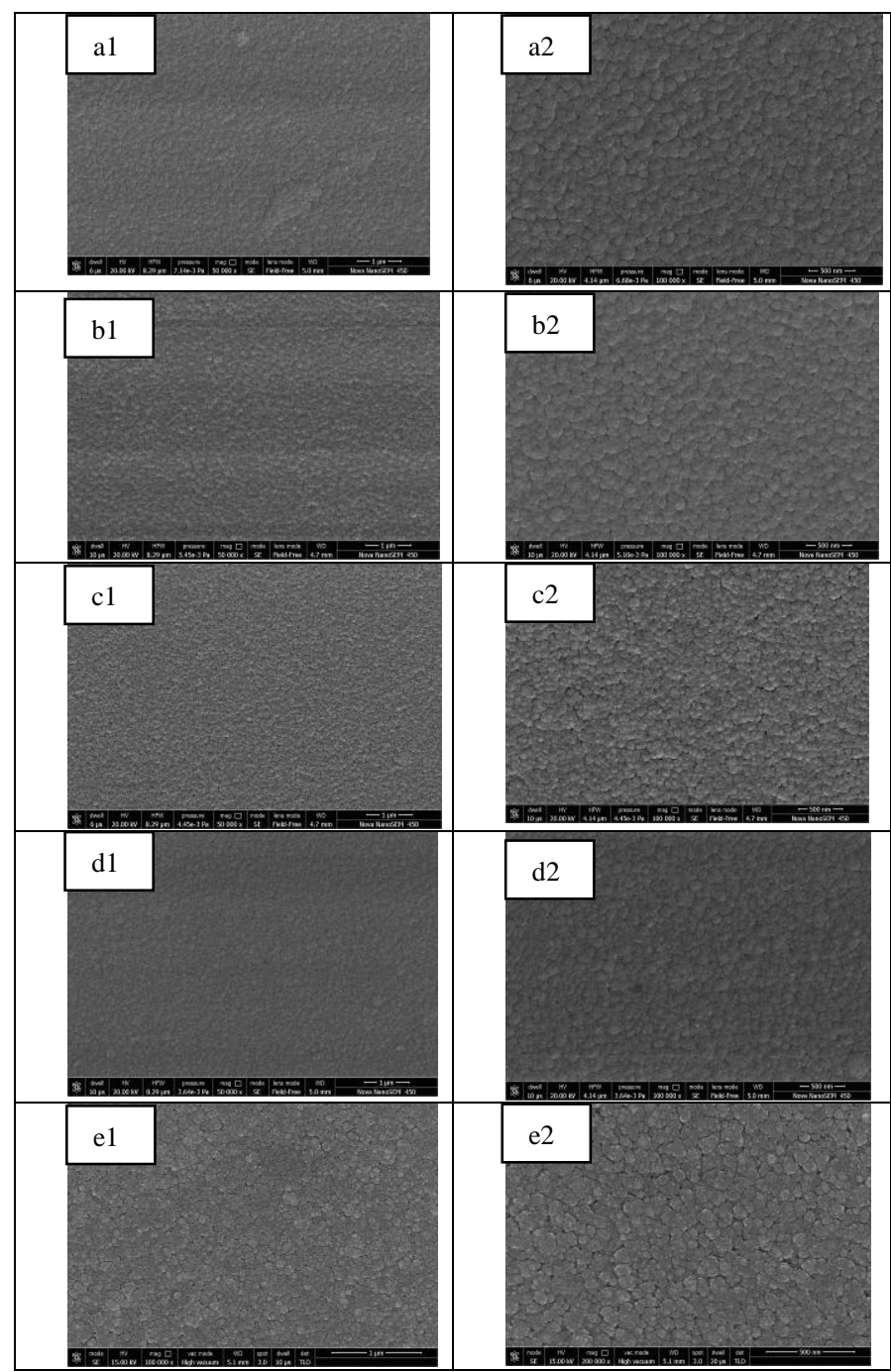

Fig. 3: SEM Images of Ti-Nb Alloys at Different Magnification a(1) 100k, a(2) 200k of Ti90Nb10, b(1) $100 \mathrm{k}, \mathrm{b}(2) 200 \mathrm{k}$ of Ti80Nb20, c(1) 100k, c(2) 200k of Ti70Nb30, d(1) 100k, d(2) 200k of Ti60Nb40, e(1) $100 \mathrm{k}$, e(2) $200 \mathrm{k}$ of $\mathrm{Ti50Nb50}$ at $100^{\circ} \mathrm{C}$

Grain sizes of alloys, as determined by FESEM are given in Table 3. It can be readily seen from the table that with increase in $\mathrm{Nb}$ content in alloy from $\mathrm{Ti} 90 \mathrm{Nb} 10$ to $\mathrm{Ti} 50 \mathrm{Nb} 50$, the grain size, in general, decreases from $104 \mathrm{~nm}$ to $46 \mathrm{~nm}$, with an exception of the sample Ti60Nb40, which exhibited an increase in grain size to $65 \mathrm{~nm}$.

Table 3: Grain size of $\mathrm{Ti}-\mathrm{Nb}$ alloy at $300^{\circ} \mathrm{C}$

\begin{tabular}{|l|l|l|l|l|l|}
\hline $\begin{array}{l}\text { Sample } \\
\text { composition }\end{array}$ & $\begin{array}{l}\text { Ti90Nb } \\
10\end{array}$ & $\begin{array}{l}\text { Ti80Nb } \\
20\end{array}$ & $\begin{array}{l}\text { Ti70Nb } \\
30\end{array}$ & $\begin{array}{l}\text { Ti60Nb } \\
40\end{array}$ & $\begin{array}{l}\text { Ti50Nb } \\
50\end{array}$ \\
\hline $\begin{array}{l}\text { Grain size } \\
\text { (in nm) }\end{array}$ & 104 & 98 & 60 & 65 & 46 \\
\hline
\end{tabular}


Titanium-Niobium Alloy Thin Films at Substrate Temperature (100C,200C and 300C) using Field Emission Scanning Electron Microscopy

It has further been noticed from the micrographs that an increase in $\mathrm{Nb}$ content led to increased homogeneity of distribution of Ti and Nb on SEM images. Density of films has increased with lesser fraction of voids. It is evident that with the increase in $\mathrm{Nb}$ content, the morphology of the grain changes and becomes denser due to higher surface area and bulk diffusivity of sputtered atoms. Trend of variation of grain sizes of alloy thin films deposited at $100^{\circ} \mathrm{C}$ and $300^{\circ} \mathrm{C}$ substrate temperatures as a function of composition are similar, however, the alloy films deposited at $200^{\circ} \mathrm{C}$ exhibited a trend of continuous decrease in grain size of lower values with increasing $\mathrm{Nb}$ content.

EDX: - In order to identify various phases and elemental compositions of $\mathrm{Ti}-\mathrm{Nb}$ alloys present in the recorded micrographs, we have performed Energy Dispersive X-Ray Microanalysis (EDX) on these samples and the EDX spectra of all the samples are shown in Fig. 4(a-e). Table 4 shows the results of elemental analysis obtained from these investigations. The composition of a thin film sample shown in table is the averages of the compositions obtained for thin films deposited at $100^{\circ} \mathrm{C}, 200^{\circ} \mathrm{C}$ and $300^{\circ} \mathrm{C}$ substrate temperatures. The chemical compositions as determined for all the $\mathrm{Ti}-\mathrm{Nb}$ thin films samples i.e. the $\mathrm{Ti}$ and $\mathrm{Nb}$ percentages validate the actual compositions of samples (i.e. compositions of the targets used).
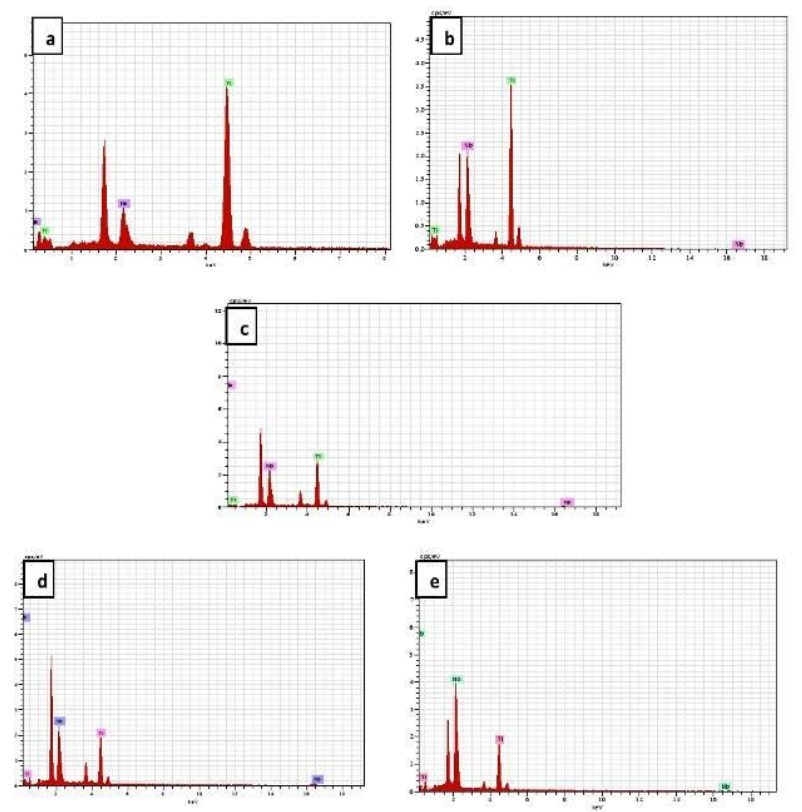

Fig. 4: EDX Patterns for Ti-Nb Alloy Samples (a)

Ti90Nb10, (b) Ti80Nb20, (c) Ti70Nb30, (d) Ti60Nb40, (e) Ti50Nb50

Table 4: EDX Chemical Analysis of all five Ti-Nb Alloy

Samples

\begin{tabular}{|c|l|l|l|l|l|l|l|}
\hline S.No & Target & $\begin{array}{l}\text { Eleme } \\
\text { nt }\end{array}$ & Series & $\begin{array}{l}\text { Ato } \\
\text { mic } \\
\text { Num } \\
\text { ber }\end{array}$ & $\begin{array}{l}\text { Weig } \\
\text { ht } \%\end{array}$ & At\% & $\begin{array}{l}\text { Error } \\
\text { wt\% }\end{array}$ \\
\hline 1 & $\begin{array}{l}\text { Ti90N } \\
\text { b10 }\end{array}$ & Ti & $\begin{array}{l}\text { K-Serie } \\
\text { s }\end{array}$ & 22 & 82.05 & 89.87 & 1.69 \\
\cline { 2 - 8 } & $\mathrm{Nb}$ & $\begin{array}{l}\text { L-Serie } \\
\text { s }\end{array}$ & 41 & 17.95 & 10.13 & 0.55 \\
\hline 2 & $\begin{array}{l}\text { Ti80N } \\
\text { b20 }\end{array}$ & Ti & $\begin{array}{l}\text { K-Serie } \\
\text { s }\end{array}$ & 22 & 70.04 & 81.94 & 1.47 \\
\hline
\end{tabular}

\begin{tabular}{|r|l|l|l|l|l|l|l|}
\hline & & $\mathrm{Nb}$ & $\begin{array}{l}\text { L-Serie } \\
\text { s }\end{array}$ & 41 & 29.96 & 18.06 & 0.85 \\
\hline 3 & $\begin{array}{l}\text { Ti70N } \\
\mathrm{b} 30\end{array}$ & $\mathrm{Ti}$ & $\begin{array}{l}\text { K-Serie } \\
\text { s }\end{array}$ & 22 & 54.27 & 67.18 & 1.05 \\
\cline { 3 - 8 } & $\mathrm{Nb}$ & $\begin{array}{l}\text { L-Serie } \\
\mathrm{s}\end{array}$ & 41 & 45.73 & 32.82 & 0.48 \\
\hline 4 & $\begin{array}{l}\mathrm{Ti60N} \\
\mathrm{b} 40\end{array}$ & $\mathrm{Ti}$ & $\begin{array}{l}\text { K-Serie } \\
\text { s }\end{array}$ & 22 & 43.82 & 58.88 & 0.86 \\
\cline { 3 - 8 } & $\mathrm{Nb}$ & $\begin{array}{l}\text { L-Serie } \\
\mathrm{s}\end{array}$ & 41 & 56.18 & 41.12 & 1.42 \\
\hline 5 & $\begin{array}{l}\text { Ti50N } \\
\mathrm{b} 50\end{array}$ & $\mathrm{Ti}$ & $\begin{array}{l}\text { K-Serie } \\
\mathrm{s}\end{array}$ & 22 & 33.45 & 49.38 & 0.65 \\
\cline { 3 - 8 } & $\mathrm{Nb}$ & $\begin{array}{l}\text { L-Serie } \\
\mathrm{s}\end{array}$ & 41 & 66.55 & 50.62 & 2.25 \\
\hline
\end{tabular}

In order to investigate the effect of substrate temperature on the microstructural aspects of the deposited $\mathrm{Ti}-\mathrm{Nb}$ films, grain sizes of various samples as obtained from FESEM studies, have been plotted against substrate temperature (Fig. 5).

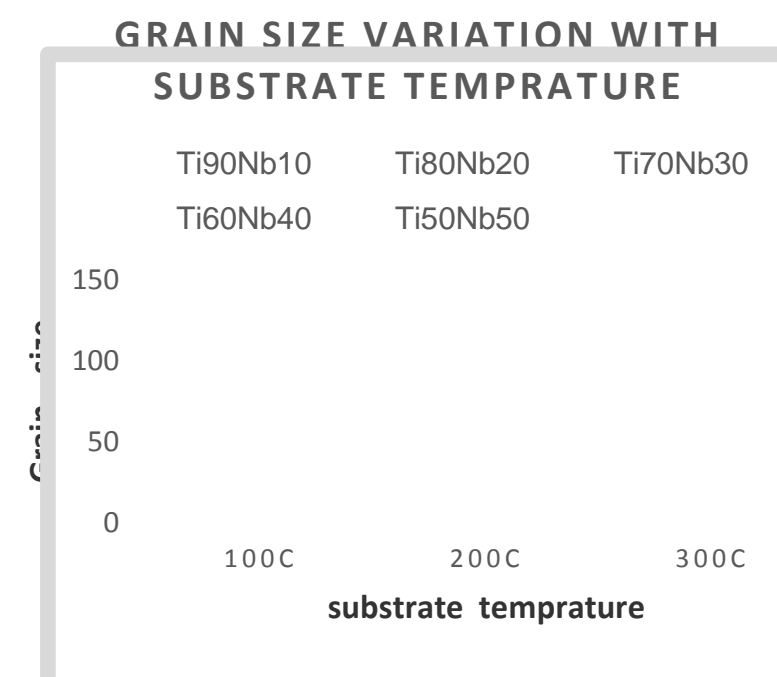

Fig 5:- Grain size variation with substrate temperature

The figure 5 clearly indicates the effect of change of substrate temperature on the grain size. With increase in substrate temperature from $100^{\circ} \mathrm{C}$ to $300^{\circ} \mathrm{C}$, the grain size exhibited a characteristic trend of variation. For all the samples except Ti50Nb50, the grain size is first found to decrease up to $200^{\circ} \mathrm{C}$ and then increase. However, the values of grain sizes obtained for these samples at $300^{\circ} \mathrm{C}$ are always less than the values at $100^{\circ} \mathrm{C}$. The sample $\mathrm{Ti} 50 \mathrm{Nb} 50$, however, found to behave entirely differently. For this sample, the grain size is found to increase monotonously from $21 \mathrm{~nm}$ to $46 \mathrm{~nm}$ as the substrate temperature increases from $100^{\circ} \mathrm{C}$ to $300^{\circ} \mathrm{C}$.

\section{CONCLUSION}

The fine grained ( $\mathrm{Ti}-\mathrm{Nb})$ alloys with nominal compositions Ti90Nb10 (Ti-17.7 wt.\% Nb),Ti80Nb20(Ti-33 wt.\% Nb), Ti 70Nb30(Ti-45 wt.\% Nb), Ti60Nb40 (Ti-56 wt.\% Nb) and Ti50Nb50 (Ti-66 wt.\% Nb) were successfully prepared by $\mathrm{RF}$ sputtering method at relatively low temperatures of $100^{\circ} \mathrm{C}, 200^{\circ} \mathrm{C}$ and $300^{\circ} \mathrm{C}$. Experimental results indicate that microstructural properties of $\mathrm{Ti}-\mathrm{Nb}$ alloys are sensitive to $\mathrm{Nb}$ content. FESEM images of the

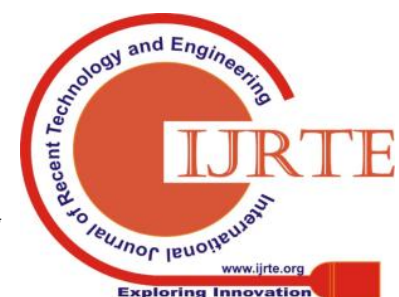


films show a uniform and dense morphology of alloy thin films in case of samples with higher $\mathrm{Nb}$ content. At $100^{\circ} \mathrm{C}$, the average grain size is found to decrease from $114 \mathrm{~nm}$ (Ti90Nb10) to $21 \mathrm{~nm}\left(\mathrm{Ti50Nb50)}\right.$. At $200^{\circ} \mathrm{C}$, the average grain size is found to decrease from $59 \mathrm{~nm}$ (Ti90Nb10) to 35 $\mathrm{nm}(\mathrm{Ti} 50 \mathrm{Nb} 50)$. At $300^{\circ} \mathrm{C}$, the average grain size is found to decrease from $104 \mathrm{~nm}$ (Ti90Nb10) to $46 \mathrm{~nm}$ (Ti50Nb50). FESEM images show that samples are adequately homogeneous. The films are found to show a decreasing trend in grain size with increasing $\mathrm{Nb}$ content. The decrease in grain size attributes the smoother surface, reduced grain boundaries and therefore, improved morphology. The effect of substrate temperature on grain size of the deposited $\mathrm{Ti}-\mathrm{Nb}$ films is also noteworthy. As the substrate temperature increases from $100^{\circ} \mathrm{C}$ to $300^{\circ} \mathrm{C}$, the grain size exhibited a characteristic trend of variation. For all the samples except Ti50Nb50, the grain size is first found to decrease up to $200^{\circ} \mathrm{C}$ and then increase. The sample Ti50Nb50, however, found to show a monotonous increase in grain size with the increase in substrate temperature.

\section{Conflict of Interest: None}

Acknowledgement: Authors acknowledge to all those who directly or indirectly contribute in this work.

\section{REFERENCES}

1. C.L. Smith, M.R. L, M. MacKenzie "New opportunities for nanomineralogy using FIB, STEM/EDX and TEM Microsc Analysis", 111 (2006), pp. 17-20

2. M. Nakagawa, R. Dunne, H. Koike, M. Sato, J.J. Pérez-Camacho, B.J Kennedy "Low voltage FE-STEM for characterization of state-of-the-art silicon” SRAM J Electron Microsc, 51 (2002), pp. 53-57

3. J. Russias, F. Frizon, C. Cau-Dit Coumes, A. Malchère, T. Douillard, C. Joussot-DubienzIn "corporation of aluminum into C-S-H structures: from synthesis to nanostructural characterization" J Am Ceram Soc, 91 (2008), pp. 2337-2342

4. $\quad$ 4R.Lal, S.A.John, "J.Phycol”. 266, CI(1994)

5. 5G.Masse, M.Poulin, S.T.Belt, J.M.Robert, A.Barreaus, Y.Rince, S.J.Rowland, J.Microsc. 204, 87 (2001)

6. 6N.Almqvist, Y.Delamo, B.L.Smith, N.H.Thomson, A.Bartholdson, R.Lal, M. Brzezinski, P.K.Hansma, J.Microsc. 202, 518(2003)

7. A.F. Yetim, F. Yildiz, Y. Vangolu, A. Alsaran, A. Celik "Several plasma diffusion processes for improving wear properties of Ti6Al4V alloyWear", 267 (2009), pp. 2179-2185

8. M.De Stefano, W.H.C.F.Kooistra, D.Marino, "J.Phycol." 39, 735(2003)

9. E.Kiefer, L.Sigg, P.Schosseler, “ Environt.Sci.Technol”. 31, 759 (1997)

10. S.A.Craford, M.J.Higgins, P.Mulvaney, R.Wetherbee, "J.Phycol”. 37, 543(2001) 17.

11. M.J.Higgins, J.E.Sader, P.Mulvaney, R.Wetherbee, "J.Phycol”. 39, 7229 (2003)

12. Linder, J.Colchero, H.J.Apell, O.Marti, J.Mlynek, "Ultramicroscopy" 42, 329 (1992) 19

13. I.C.Gebeshuber, J.H.Kindt, J.B.Thompson, Y.Del Amo, H.Stachelberger, M.A.Brzezinski, G.D.Stucky, D.E.Morse, P.K.Hansma, “J.Microsc”. 212, 292(2003)

\section{AUTHORS PROFILE}

1. Aditi, Department of applied sciences, Punjab technical University 2. Dr. Anand K.Tyagi, Professor, SBS State Technical Campus, Ferozpur (Punjab) 